DOI https://doi.org/10.30525/978-9934-26-111-4-12

\title{
ОЦІНКА ПЕРОРАЛЬНОГО НАДХОДЖЕННЯ ЗАЛІЗА І МАРГАНЦЮ 3 ПИТНОЮ ВОДОЮ ДЛЯ ДИТЯЧОГО НАСЕЛЕННЯ ЖИТОМИРСЬКОЇ ОБЛАСТІ
}

\author{
Валерко Р. А. \\ кандидат сільськогосподарських наук, \\ доиент кафедри загальної екології \\ Поліський національний університет
}

Герасимчук Л. О. кандидат сільськогосподарських наук, дочент кафедри загальної екології Поліський національний університет

\section{Приходько А. П.}

здобувач вищої освіти освітнього ступеня магістр спечіальності 101 «Екологія»

Поліський начіональний університет м. Житомир, Украӥна

Доступ до централізованого водопостачання та водовідведення у країнах Свропейського Союзу має 90 \% населення. В Україні, наразі, лише 58,7 \% населення мають доступ до централізованого водопостачання і 37,6 - до централізованого водовідведення. Водорозподільча мережа $є$ доступною для 87,2 \% міського населення України і лише для 29 \% сільського населення. Не є виключенням у цьому сенсі й Житомирська область, яка займає 20 місце серед інших регіонів України за показником забезпечення населення селищ міського типу i 17 місце щодо забезпечення сільського населення централізованим водопостачанням [2].

У сільській місцевості, яка не оснащена системами централізованого водопостачання та водовідведення, мешканці домогосподарств використовують неочищені підземні води невідомої якості [1], не розуміючи можливих наслідків для власного здоров'я [5], а тому, оцінка ризику для здоров'я людини, особливо дитячого населення, внаслідок споживання питної води, забрудненої металами, $\epsilon$ питанням досить гострим та актуальним. 
Дослідження проходили у межах Житомирської області, на території сільських населених пунктів Бердичівського, Житомирського, Коростенського та Новоград-Волинського районів. Зразки води відбирали із колодязів та свердловин, які розташовані на території закладів дошкільної та шкільної освіти. Загалом було відібрано 114 зразків питної води. Аналітичні дослідження води на вміст заліза, марганцю та нітратів здійснювали у Вимірювальній лабораторії Поліського національного університету.

Встановлено, що середній вміст заліза загального у питній воді, яка відібрана у закладах освіти на території Житомирської області коливався від 1,0 до 2,8 мг/дм ${ }^{3}$, відсоток проб із перевищенням його вмісту варіював від 41 до 53,3\%. Середній вміст марганцю знаходився у межах нормативу, а перевищення його концентрації зафіксовано у Житомирському, Коростенському та Новоград-Волинському районах (табл. 1).

Таблиця 1

Вміст заліза і марганцю у питній воді сільських населених пунктів Житомирської області

\begin{tabular}{|c|c|c|c|c|}
\hline Райони & $\begin{array}{c}\text { Середній } \\
\text { вміст, } \\
\text { мг/дм }\end{array}$ & $\begin{array}{c}\text { Інтервал } \\
\text { значень }\end{array}$ & $\begin{array}{c}\text { Кількість } \\
\text { проб } \\
\text { 3 перевищенням } \\
\text { нормативу, \% }\end{array}$ & $\begin{array}{c}\text { Норматив, } \\
\text { мг/дм }\end{array}$ \\
\hline \multicolumn{5}{|c|}{ Залізо загальне } \\
\hline Бердичівський & 2,8 & $0,1-10,6$ & 42,9 & 1,0 \\
\hline Житомирський & 2,2 & $0,004-9,8$ & 53,3 & 1,0 \\
\hline Коростенський & 1,0 & $0,08-5,5$ & 35 & 1,0 \\
\hline $\begin{array}{c}\text { Новоград- } \\
\text { Волинський }\end{array}$ & 1,5 & $0,1-10,6$ & 41 & 1,0 \\
\hline \multicolumn{5}{|c|}{ Марганеиьь } \\
\hline Бердичівський & 0,1 & $\begin{array}{c}0,005- \\
0,29\end{array}$ & 0,5 \\
\hline Житомирський & 0,19 & $\begin{array}{c}0,005- \\
1,61\end{array}$ & 0,5 \\
\hline Коростенський & 0,16 & $\begin{array}{c}0,005- \\
0,84\end{array}$ & 12 & 0,5 \\
\hline $\begin{array}{c}\text { Новоград- } \\
\text { Волинський }\end{array}$ & 0,36 & $\begin{array}{c}0,005- \\
1,95\end{array}$ & 19,4 & 0,5 \\
\hline
\end{tabular}

Після знаходження середнього та максимального вмісту заліза i марганцю відповідно до методики оцінки ризику USEPA (US Environmental Protection Agency, 2004) [4] були розраховані 
середньодобові дози надходження даних елементів до організму дітей та підлітків внаслідок споживання води (табл. 2).

Таблиця 2

Результати оцінки перорального надходження заліза і марганцю 3 питною водою для дитячого населення Житомирської області

\begin{tabular}{|c|c|c|c|c|c|c|c|c|}
\hline \multirow{2}{*}{ Райони } & \multicolumn{4}{|c|}{ Залізо загальне } & \multicolumn{4}{c|}{ Марганець } \\
\cline { 2 - 9 } & сер & макс & сер & макс & сер & макс & сер & макс \\
\hline $\begin{array}{c}\text { Берди- } \\
\text { чівський }\end{array}$ & 0,13 & 0,51 & 0,08 & 0,32 & 0,005 & 0,014 & 0,003 & 0,009 \\
\hline $\begin{array}{c}\text { Жито- } \\
\text { мирський }\end{array}$ & 0,1 & 0,47 & 0,07 & 0,3 & 0,009 & 0,08 & 0,006 & 0,05 \\
\hline $\begin{array}{c}\text { Коростен } \\
\text { ський }\end{array}$ & 0,05 & 0,26 & 0,03 & 0,17 & 0,008 & 0,04 & 0,005 & 0,03 \\
\hline $\begin{array}{c}\text { Ново- } \\
\text { град- } \\
\text { Волинсь- } \\
\text { кий }\end{array}$ & 0,07 & 0,51 & 0,05 & 0,32 & 0,02 & 0,09 & 0,01 & 0,06 \\
\hline
\end{tabular}

Оцінка ризику для здоров'я людини внаслідок забруднення питної води залізом та марганцем проходила 3 використанням коефіцієнту небезпеки (табл. 3).

Таблиця 3

Критерії неканцерогенного ризику

\begin{tabular}{|c|c|c|}
\hline Характеристика ризику & $\begin{array}{c}\text { Коефіціснт } \\
\text { небезпеки (НQ) }\end{array}$ & $\begin{array}{c}\text { Рівень } \\
\text { небезпеки }\end{array}$ \\
\hline $\begin{array}{c}\text { Ризик виникнення шкідливих } \\
\text { ефектів відсутній }\end{array}$ & $\leq 0,1$ & Мінімальний \\
\hline $\begin{array}{c}\text { Ризик виникнення шкідливих } \\
\text { ефектів є зневажливо малим }\end{array}$ & $0,1-1$ & Низький \\
\hline $\begin{array}{c}\text { Ризик розвитку шкідливих } \\
\text { ефектів в особливо чутливих } \\
\text { групах населення }\end{array}$ & $1-5$ & Високий \\
\hline $\begin{array}{c}\text { Ризик розвитку несприятливих } \\
\text { ефектів у більшої частини } \\
\text { населення }\end{array}$ & $5-10$ & $\begin{array}{c}\text { Надзвичайно } \\
\text { високий }\end{array}$ \\
\hline $\begin{array}{c}\text { Масові скарги, виникнення } \\
\text { хронічних захворювань }\end{array}$ & $\geq 10$ & \\
\hline
\end{tabular}


Встановлено, що найбільший внесок у величину неканцерогенного ризику для здоров'я дитячого населення сільських населених пунктів Житомирської області робить залізо загальне. Ця величина коливається у межах від 0,1 , що характеризується як зневажливо малий ризик, до 1,7 - що становить середній ризик (рис. 1). Установлено також, що величина ризику є більшою для дітей, ніж для підлітків.

Коефіцієнт небезпеки, зумовлений вмістом марганцю, у жодному випадку не перевищував 1 навіть при максимальних його концентраціях, що свідчить про низький ризик виникнення шкідливих ефектів (рис. 1). Проте, проведеними на території Харківської області дослідженнями доведено, що постійне споживання води, величина коефіцієнту небезпеки для якої за вмістом марганцю і заліза становить 0,05 , може викликати небезпеку ураження нирок, шлунково-кишкового тракту, центральної нервової системи, захворювання серцево-судинної системи [3].

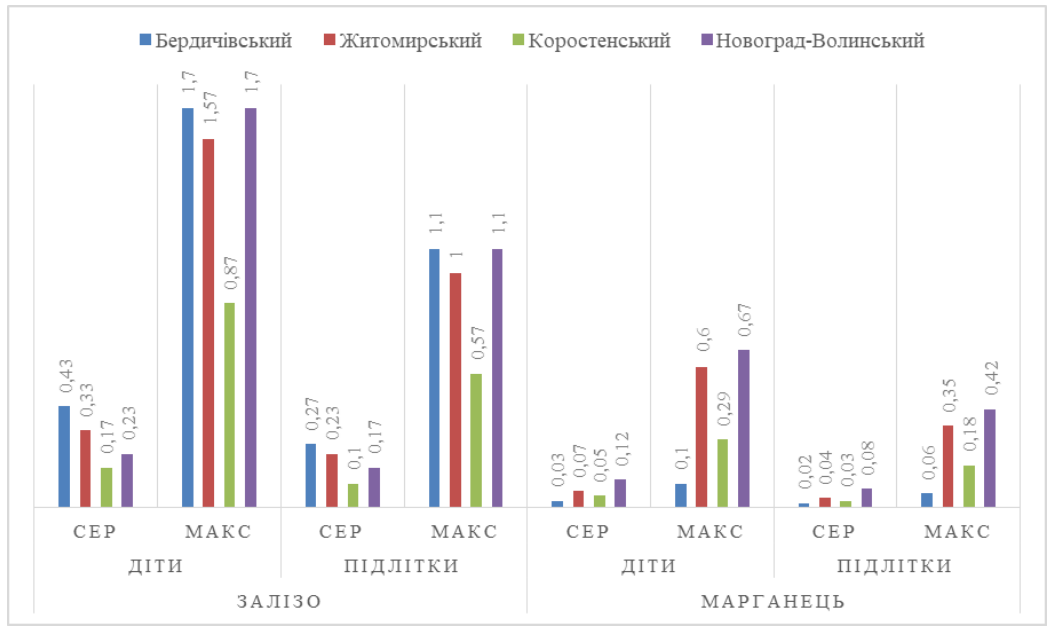

\section{Рис. 1. Величина ризику для дитячого населення залежно від вмісту у питній воді заліза і марганцю}

Таким чином, найбільший внесок у сумарний ризик робить залізо загальне, оскільки найбільша величина коефіцієнту небезпеки становить 1,7 , що характеризується як середній рівень ризику. Для марганцю максимальне значення коефіцієнту небезпеки зафіксовано на рівні 0,67 , що визначається як зневажливо малий ризик виникнення 
шкідливих ефектів. Крім того, слід зазначити, що величина ризику $є$ більшою для дітей віком 0-6 років, ніж для підлітків.

\section{Лiтература:}

1. Герасимчук Л. О., Валерко Р. А. Якість води джерел нецентралізованого водопостачання на території сільських населених пунктів Житомирської області. Екологічні науки. 2021. 7 (34). С. 145-150. DOI https://doi.org/10.32846/2306-9716/2021.eco.7-34.24.

2. Національна доповідь про якість питної води та стан питного водопостачання в Україні у 2019 році. URL: https://www.minregion.gov.ua/wp-content/uploads/2020/11/proektnacz.-dop.-za-2019.pdf.

3. Прибилова В. М., Качан А. М. Хімічний склад підземних вод Харківської області як фактор ризику для здоров'я населення. Вісник Харківського національного університету ім. В.Н. Каразіна. Сер. «Геологія. Географія. Екологія». 2017. Вип. 46. С. 37-45. https://doi.org/10.26565/2410-7360-2017-46-04.

4. Руководство по оценке риска для здоровья населения при воздействии химических веществ, загрязняющих окружающую среду. URL: https://ohranatruda.ru/ot_biblio/normativ/data_normativ/46/46715/

5. Romanchuk L. D., Valerko R. A, Herasymchuk L. O., Kravchuk M. M. Assessment of the impact of organic agriculture on nitrate content in drinking water in rural settlements of Ukraine. Ukrainian Journal of Ecology. 2021. 11(2): 17-26. DOI: 10.15421/2021_71. 